\title{
The Influence of Organizational Culture, Compensation, and Work Environment on Employee Performance in Class IIB Bangko Correctional Institutions
}

\author{
Anggara Bratama ${ }^{1}$; Erianjoni ${ }^{2}$ \\ Public Administration Faculty of Social Science of Padang State University ${ }^{1,2}$ \\ E-mail:Anggarabratama12345@gmail.com
}

(Received: May 17-2020; revised: Juny 10-2020; published: December 31-2020)

\begin{abstract}
Organizational culture is a system of values, beliefs and habits in an organization that interact with each other's formal system structure for organizational behavior norms. According to Ahmed's research. et al (2014) organizational culture is a combination of values, beliefs, communication and simplification of behavior that provides direction to society. The basic idea of culture arises through sharing a learning process that is based on the appropriate allocation of resources. A professional employee cannot escape the fact that they are individuals who also have needs, wants and expectations from where they work. The State Civil Apparatus as a public servant profession has been regulated in Law No. 5/2014 on several principles, one of which is commitment, moral integrity, and responsibility for public services. The desire to fulfill this need will affect the compensation that exists for each individual to do things better than others in carrying out activities to achieve goals. The purpose of providing compensation includes cooperation, job satisfaction, effective procurement, employee stability. Compensation is also an award given to employees, either directly or indirectly, financially or non-financially, which is fair to employees or their contribution to achieving organizational goals, so that compensation is needed by any organization to increase employee job satisfaction. This study aims to reveal the influence of organizational culture, compensation, and work environment on employee performance at the Bangko Class II Penitentiary, either directly or indirectly for Bangko Class II B Prison employees. This study uses a quantitative method, with exogenous variables, namely organizational culture (X1), compensation (X2), work environment intervening variables (X3) and endogenous variables, namely employee performance (Y) at Bangko Class II Correctional Institution (Lapas). The population of this research is all employees of Lapas in Bangko Class II Correctional Institution, namely 55 people. The sample was obtained through total sampling so that the respondents in this study amounted to 55 samples. The data analysis technique used is path analysis and is divided into 2 paths, namely sub-structure 1 and sub-structure 2. Data is collected through a questionnaire that has been validated and reliable in advance, both content and empirical test of items in the field.
\end{abstract}

Keywords: Organizational Culture, Compensation, Work Environment, and Employee Performance

\section{INTRODUCTION}

Organization is a system that affects each other, if one of the subsystems is damaged, it will affect other sub-systems. The system can run properly if the individuals in it are obliged to regulate it, which means that as long as the members or individuals still like and carry out their responsibilities properly, the organization will run well.

Human resources are very valuable assets in achieving organizational goals. It cannot be denied that the human factor has a very important role in running an organization. 
One of the factors that can satisfy workers in their jobs is traditional incentives or wages. Furthermore, he said, it seems that a person is satisfied with high wages, even though this relationship is not always consistent. Therefore, the level of employee job satisfaction must be considered by the leadership so that employees can do their job better and encourage the creation of high morale. With high morale, employees can do their jobs on time, reduce absenteeism and make employees feel at home or happy. The theoretical and empirical improvement in employee performance in public organizations can be influenced by several factors, such as organizational culture, compensation, and work environment factors.

Wibowo (2011) argues that performance comes from the notion of performance. According to Armstrong and Baron in Wibowo (2011) performance is the result of work that has a strong relationship with the organization's strategic goals, customer satisfaction, and contributes to the economy. Thus performance is about doing the job and the results achieved from that job. Performance is about what to do and how to do it.

Organizational culture is a system of values, beliefs and habits in an organization that interact with each other's formal system structure for organizational behavior norms. According to Ahmed's research et al (2014) organizational culture is a combination of values, beliefs, communication and simplification of behavior that provides direction to society. The basic idea of culture arises through sharing a learning process that is based on the appropriate allocation of resources.

Moorhead and Griffin (2013) say organizational culture as a set of values that is accepted is always true, which helps someone in the organization to understand which actions are acceptable and which actions are not accepted and these values are communicated through stories and symbolic ways. other.

A professional employee cannot escape the fact that they are individuals who also have needs, wants and expectations from where they work. The State Civil Apparatus as a public servant profession has been regulated in Law No. 5/2014 on several principles, one of which is commitment, moral integrity, and responsibility for public services. The desire to fulfill this need will affect the compensation that exists for each individual to do things better than others in carrying out activities to achieve goals. According to Hasibuan (2014: 118) compensation is all income in the form of money, direct goods, or indirectly received by employees as compensation for services provided to the company. The purpose of providing compensation includes cooperation, job satisfaction, effective procurement, employee stability. Compensation is also an award given to employees, either directly or indirectly, financially or non-financially, which is fair to employees or their contribution to achieving organizational goals, so that compensation is needed by any organization to increase employee job satisfaction.

For some employees, the hope of getting money is the only reason to work, but others argue that money is only one of many needs that are met through work. Someone who works will feel more valued by the surrounding community, compared to not working. To ensure the achievement of goal alignment, leaders can pay attention by providing compensation, because compensation is part of a reciprocal relationship between the organization and human resources.

Therefore, one of the best ways to increase employee satisfaction capacity is to link compensation to employee development. If the compensation program is felt to be fair and competitive by employees, it will be easier for organizations to attract potential employees.According to Nitisemito (2000) the work environment is everything that is around the workers and can 
influence them in carrying out their assigned tasks. The work environment consists of physical and non-physical environments that are inherent to employees, so that it cannot be separated to get good employee performance.

The work environment also determines the improvement of employee performance, the success of public organizations is also largely determined by organizational capabilities

in designing a good work environment. The work environment is very important to note, the work environment is a place where employees work everyday. A comfortable, conducive work environment will improve employee performance.The Class II B Bangko Penitentiary as one of the institutions responsible for implementing bureaucratic reform through the correctional system under the auspices of the Ministry of Law and Human Rights (Kemenkumham) which receives remuneration and compensation is expected to reinforce the reward and punishment mechanism.

Based on preliminary observations made by the author at the Class II B Bangko Penitentiary, which has 55 employees and 368 prisoners, it turns out that gaps are not in accordance with idealism, it appears that the compensation given is not optimal, there are still employees. those who postpone work, there are still employees who are not on time when they go to the office, incomplete facilities and infrastructure, there are still some work rooms that do not have air conditioning or air conditioning, there are no sound absorbers that cause noise.

This must be considered by a leader of the Correctional Institution, in order to be able to overcome the problems that will arise from this phenomenon as early as possible and try to improve the quality of human resource management that is in the Penitentiary. How is it possible to achieve the goals of an organization / agency many employees who do not care about the work for which they are responsible. Even though employees have a very big role in developing their potential in organizing and running and implementing good services. Of course there are many factors that make an organization / agency strive to provide solutions to existing deficiencies.

\section{METHOD}

The method used by researchers is a quantitative method using structural equations, namely the causal dimensions of the influence of organizational culture (X1) and compensation (X2) on the work environment (X3); the influence of organizational culture (X1) and compensation (X2) on employee performance (Y). The data collection technique used in the study was (1) creating a questionnaire which included a list of questions that referred to the research variables which were later distributed to respondents. The arrangement of instruments for the measured variables is made in the form of positive and negative statements, so that respondents can answer seriously and consistently. The results will be displayed in a frequency table, and then the data (these numbers) will be analyzed through path analysis. (2) Documentation study by collecting data that will be needed in this research by collecting and studying documents related to this research, such as books, journals, newspapers and secondary data on job satisfaction, work motivation, morale and employee integrity. (3) Direct observations (field observations) are carried out by the author at the research location to see social facts and facts so that they can be matched 
between the results of interviews or information from informants with facts in the field. The conception of the research of researchers is that the path analysis model is used to analyze the pattern of relationships between variables in order to determine the direct and indirect effect of the independent (exogenous) variable on the dependent variable (endogenous).

\section{RESULT AND DISCUSSION}

\section{a. Organizational Culture (X1)}

To see a description of each indicator of organizational culture variables can be seen in the following table:

Table (1) Description of Organizational Culture Variable Indicators

\begin{tabular}{|c|c|c|c|c|c|}
\hline No. & Statement & $\mathbf{N}$ & Mean & $\begin{array}{l}\text { TCR } \\
(\%)\end{array}$ & Ket \\
\hline 1 & $\begin{array}{l}\text { Have high innovation and have } \\
\text { the courage to take risks. }\end{array}$ & 55 & 3.76 & 75.27 & High \\
\hline 2 & $\begin{array}{l}\text { Do not have a thorough attitude } \\
\text { in doing work (details). }\end{array}$ & 55 & 3.30 & 66.18 & High \\
\hline 3 & Result oriented. & 55 & 3.47 & 69.45 & High \\
\hline 4 & $\begin{array}{l}\text { Oriented to fellow employees } \\
\text { in the office. }\end{array}$ & 55 & 3.43 & 68.72 & High \\
\hline 5 & $\begin{array}{l}\text { Team oriented. } \\
\text { The organizational culture that }\end{array}$ & $\begin{array}{l}55 \\
55\end{array}$ & 3.61 & 72.36 & High \\
\hline 6 & $\begin{array}{l}\text { I have to apply in my office is } \\
\text { aggressiveness. }\end{array}$ & & 3.38 & 67.63 & High \\
\hline 7 & $\begin{array}{l}\text { An employee must have } \\
\text { stability in doing work. }\end{array}$ & 55 & 3.43 & 68.72 & High \\
\hline & Variable Mean & & 3.48 & 69.76 & High \\
\hline
\end{tabular}

and an employee must have stability in doing work in the "High" category with a mean score of 3.43 and a TCR of $68.72 \%$. In general, it can be said that organizational culture is still in the "High" category with a score of 3.48 and a TCR of $69.76 \%$.

Thus it can be said that the organizational culture felt by employees in general in this study is like having high innovation and having the courage to take risks, not having a thorough attitude in doing work (details), result oriented, oriented towards fellow employees in the office. , team-oriented, the organizational culture that I have to apply in my office is aggressiveness, an employee must have stability in doing work even though he is already in the high category, it is still expected that the employees of Bangko Class II Correctional Institution (Lapas) can improve organizational culture. If the organizational culture of employees is reduced, it will have a negative impact on the service process for both fellow employees and detainees in the Bangko Class II Prison. 
420 | Jurnal Ilmiah Ilmu Administrasi Publik: Jurnal Pemikiran dan Penelitian Administrasi Publik

Volume 10 Number 2, July-December 2020. Page 416-438

\section{b. Compensation}

following table:

To see a description of each indicator of the compensation variable can be seen in the

Table (2) Description of Compensation Variable Indicators

\begin{tabular}{|c|c|c|c|c|c|}
\hline No. & Statement & $\mathbf{N}$ & Mean & $\begin{array}{l}\text { TCR } \\
(\%)\end{array}$ & Ket \\
\hline 1 & $\begin{array}{l}\text { Satisfaction with salary is not in } \\
\text { accordance with the work being } \\
\text { done. }\end{array}$ & 55 & 3.23 & 64.72 & High \\
\hline 2 & $\begin{array}{l}\text { Incentives can make performance } \\
\text { at work better. }\end{array}$ & 55 & 3.30 & 66.18 & High \\
\hline 3 & $\begin{array}{l}\text { Unexpected bonuses from the } \\
\text { leadership can increase the job. }\end{array}$ & 55 & 3.32 & 66.54 & High \\
\hline 4 & $\begin{array}{l}\text { Employees in the office must be } \\
\text { paid the same salary. }\end{array}$ & 55 & 3.38 & 67.63 & High \\
\hline 5 & $\begin{array}{l}\text { Never feel satisfied with the } \\
\text { premiums received from the } \\
\text { office (leadership). }\end{array}$ & 55 & 3.49 & 69.81 & High \\
\hline 6 & $\begin{array}{l}\text { Employees must receive proper } \\
\text { treatment in case of disaster. }\end{array}$ & 55 & 3.30 & 66.18 & High \\
\hline 7 & $\begin{array}{l}\text { Employees must have and get } \\
\text { insurance since they start } \\
\text { working from the office. }\end{array}$ & 55 & 3,2 & 64 & High \\
\hline & Variable Mean & & 3.34 & 66.84 & High \\
\hline
\end{tabular}

Based on table 12 above, it can be seen that the compensation for Bangko Class II Correctional Institutions (Lapas) can be seen from 7 indicators such as satisfaction with salaries not in accordance with the work being done is in the "High" category with a mean score of 3.23 and TCR $64.72 \%$, incentives can make performance at work better are in the "High" category with a mean score of 3.30 and a TCR of $66.18 \%$, an unexpected bonus from the leadership can increase in work being in the "High" category with a mean score of 3, 32 and TCR $66.54 \%$, employees in the office must get the same wages in the "High" category with a mean score of 3.38 and a TCR of $67.63 \%$, never satisfied with the premiums received from the office (leader ). are in the "High" category with a mean score of 3.49 and a TCR of $69.81 \%$, 


\section{c. Work environment}

To see the description of each item, the work environment variable statement can be seen in the table below:

Table (3) Description of Work Environment Variable Indicators

\begin{tabular}{|c|c|c|c|c|c|}
\hline No. & Statement & $\mathbf{N}$ & Mean & $\frac{\text { TCR }}{(\%)}$ & Ket \\
\hline 1 & $\begin{array}{l}\text { Work equipment in the office is } \\
\text { adequate (adequate). }\end{array}$ & 55 & 3,6 & 72 & High \\
\hline 2 & $\begin{array}{l}\text { Leaders do not have good service } \\
\text { at work. }\end{array}$ & 55 & 3.49 & 69.81 & High \\
\hline 3 & $\begin{array}{l}\text { Good working conditions are not } \\
\text { necessarily a reference in getting } \\
\text { maximum work results. }\end{array}$ & 55 & 3.58 & 71.63 & High \\
\hline 4 & $\begin{array}{l}\text { The attitude of building } \\
\text { cooperation and trust with leaders } \\
\text { and colleagues can be a point in } \\
\text { working success. }\end{array}$ & 55 & 3.52 & 70.54 & High \\
\hline & Variable Mean & & 3.55 & 71 & High \\
\hline
\end{tabular}

Source: Authors' processed data for 2020

Based on the description above, it can be concluded that the compensation is in the "High" category with a mean score of 3.55 and a TCR of $71 \%$. This means that the Head of Class II Bangko Prison is expected to be more committed to providing compensation to prison employees so that each employee can carry out their duties as an employee properly.

\section{d. Employee Performance ( $Y$ )}

To see the description of each item of the employee performance variable statement at the Bangko Class II Correctional Institution (Lapas) can be seen in the table below:

Table (4) Description of Employee Job Satisfaction Variable Indicators

\begin{tabular}{clcccc}
\hline No. & \multicolumn{1}{c}{ Statement } & N & Mean & TCR & Ket \\
\hline $\begin{array}{l}\text { The quality of work is good and it } \\
\text { is able to make my friends } \\
\text { motivated by the way I work. }\end{array}$ & 55 & 3.67 & 73.45 & High \\
$2 \begin{array}{l}\text { The number of absences at the } \\
\text { office has decreased (minimal). }\end{array}$ & 55 & 3.32 & 66.54 & High \\
$\begin{array}{l}\text { The friendly nature in my work } \\
\text { environment has not been } \\
\text { possessed by all employees. }\end{array}$ & 55 & 3.63 & 72.72 & High \\
$4 \begin{array}{l}\text { My initiative in work is very high } \\
\text { and no doubt. }\end{array}$ & 55 & 3.61 & 72.36 & High
\end{tabular}


422 Jurnal Ilmiah Ilmu Administrasi Publik: Jurnal Pemikiran dan Penelitian Administrasi

Publik

Volume 1o Number 2, July-December 2020. Page 416-438

All employees in the office are

5 willing to work together (team work).

$\begin{array}{llll}55 & 3.50 & 70.18 \quad \text { High }\end{array}$

$\begin{array}{lrrr}\text { Variable Mean } & 3.55 & \mathbf{7 1 . 0 5} & \text { High }\end{array}$

Source: Authors' processed data for 2020

Based on table 14 above, it can be seen that the performance of employees at Bangko Class II Correctional Institutions (Lapas) can be seen from 5 indicators such as the quality at work is good and able to make my friends motivated by the way I work. Is in the "High" category with a mean score 3.67 and a TCR of $73.45 \%$, the number of absenteeism in the office has decreased (minimal) is in the "High" category with a mean score of 3.32 and a TCR of $66.54 \%$, the nature of hospitality in my work environment has not been owned by all employees is in the "High" category with a mean score of 3.63 and a TCR of $72.72 \%$, my initiative in working is very high and no doubt in the "High" category with a mean score of 3.61 and a TCR of $72.36 \%$, all employees in the office already has a willingness to work together (team work).is in the "High" category with a mean score of 3.50 and a TCR of $70.18 \%$.

Thus it can be said that the performance of employees at Bangko Class II Correctional Institutions is still in the "High" category. This is evident from the overall mean reaching 3.55 and TCR 71.05\%. For this reason, it is hoped that all Bangko Class II Correctional Institutions (Lapas) employees can always improve their performance at work. In order to achieve the desired goals in the organization.

\section{A. Hypothesis test}

After testing the fulfillment of the analysis requirements as a research study, the researcher then tests the research hypothesis which is carried out through the following steps:

\section{Conceptual Model Submission}

Based on the results of the theoretical study, a conceptual framework of thought can be formulated, as well as a research study hypothesis such as a paradigm model of the relationship between variables.

The hypotheses to be tested based on the conceptual model are as follows:

1) There is a direct effect (X1) on (X3).

2) There is a direct effect $(\mathrm{X} 2)$ on $(\mathrm{X} 3)$.

3) There is an influence (X1) on (Y)

4) There is a direct effect $(\mathrm{X} 2)$ on $(\mathrm{Y})$.

5) There is a direct effect $(\mathrm{X} 3)$ on $(\mathrm{Y})$.

\section{Path Analysis Model}

To determine the direct effect of each variable, namely the organizational culture variable (X1) on the work environment (X3), the compensation variable (X2) on the work environment (X3), and the organizational culture variable (X1) on the employee performance (Y) in the Penitentiary (Lapas). Class II Bangko, compensation (X2) for employee 
performance (Y) Bangko Class II Penitentiary, and work environment (X3) on employee performance (Y) Class II Bangko Prison, based on the above conception can be seen in the analysis model specification, as illustrated in Figure 2 path analysis on page 69:

Based on the path analysis model, further processing can be carried out by dividing the path structure into 2 (two) groups, namely the path 1 and 2 substructure as depicted in Figure 3 and Figure 4 on page 69.

\section{Hypothesis testing}

To determine whether the previously proposed hypothesis can be accepted or rejected, the basis of testing can be used with the following criteria:

If tcount $>$ ttable or Sig value $<0.05$, the hypothesis is accepted

If tcount <ttable or Sig value >0.05, the hypothesis is rejected

From the hypothesis testing that the researchers have done, the results show that all hypotheses can be accepted, this can be seen in the explanation of each hypothesis as follows:

1) From the analysis of the influence of organizational culture (X1) on the work environment $(\mathrm{X} 3)$, the tcount $=3.631$, at sign $=0.000<0.05$, thus the hypothesis is accepted. So it can be concluded that there is a direct influence of organizational culture (X1) on the work environment (X3).

2) From the analysis of the effect of compensation (X2) on the work environment (X3), the value of $t$ count $=2.561$, at sign $=0.000<0.05$, thus the hypothesis is accepted. So it can be concluded that there is a direct effect of compensation (X2) on the work environment (X3).

3) Based on the analysis of organizational culture (X1) on employee performance (Y), the tcount $=1.204$ at sign $=0.000<0.05$, thus the hypothesis is accepted. So it can be concluded that there is a direct influence of organizational culture (X1) on employee performance (Y).

4) Likewise, based on the analysis of the effect of compensation (X2) on employee performance $(\mathrm{Y})$, the value of tcount $=1.540$, at sign $=0.000$, is thus accepted. So it can be concluded that there is a direct effect of compensation (X2) on employee performance (Y).

5) Furthermore, in the analysis of the influence of organizational culture (X1) on work environment $(\mathrm{X} 3)$ on employee performance $(\mathrm{Y})$, the value of tcount $=5.238$, at sign $=0.000$, is thus accepted. So it can be concluded that there is a direct influence on organizational culture (X1) work environment (X3) employee performance (Y).

\section{Operate the Path Analysis Model}

Based on the results of the analysis above, the operation of the path analysis model will then be described in the following stages:

\section{a. Identify the path coefficients of Sub structure 1 and Sub structure 2}

Based on the results of the multiple regression analysis, each path coefficient can be determined as follows:

Regression stage 1 Beta X13 $=0.543(\mathrm{t}=3,631)=\mathrm{p} 31$

Stage 2 regression Beta $X 23=0.114(t=2.561)=p 32$

Regression stage 1 Beta X1y $=0.092(t=1.204)=$ py 1 
424 | Jurnal Ilmiah Ilmu Administrasi Publik: Jurnal Pemikiran dan Penelitian Administrasi Publik

Volume 1o Number 2, July-December 2020. Page 416-438

Stage 2 regression Beta X2y $=0.197(\mathrm{t}=1.540)=$ py2

Stage 3 regression Beta $X 3 y=0.617(t=5.238)=$ py 3

\section{Information:}

Beta : Standard regression coefficient, used as path coefficient

p31 : path coefficient between X1 and X3

p32 : Path coefficient between $\mathrm{X} 2$ and $\mathrm{X} 3$

py1 : path coefficient between X2 and X3

py2 : path coefficient between $\mathrm{X} 1$ and $\mathrm{Y}$

py3 : path coefficient between $\mathrm{X} 3$ and $\mathrm{Y}$

\section{b. Calculating the Path Coefficient for the Residual Substructure 1}

By using a formula $\sqrt{\left(1-R^{2}\right)}$ then the path coefficient for the residuals of each dependent variable can be calculated as follows:

1) Path coefficient for residualsubstructure 2: organizational culture (X1), compensation (X2) to work environment (X3)

$$
\begin{aligned}
\mathrm{e} 1 & =\sqrt{\left(1-R^{2}\right)} \\
= & \sqrt{\left(1-0,394^{2}\right)} \\
= & \sqrt{0,844} \\
& =0.918
\end{aligned}
$$

2) Based on the results above, the path coefficient and path coefficient and residual path coefficient of Sub-structural 1 can be described as follows:

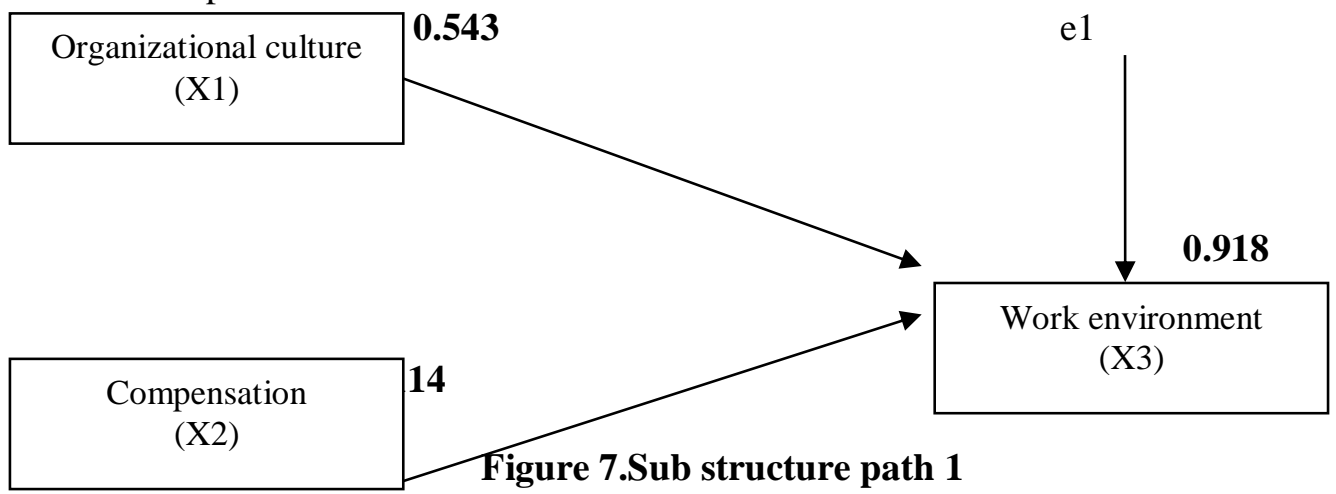

\section{c. Calculating the Path Coefficient for the Residual Substructure 2}

By using a formula $\sqrt{\left(1-R^{2}\right)}$ then the path coefficient for the residuals of each dependent variable can be calculated as follows: 
1) Path coefficient for residual sub structure 2: organizational culture (X1), compensation (X2) and work environment (X3) on employee performance (Y) at Bangko Class II Correctional Institution (Lapas).

$$
\begin{aligned}
\mathrm{e} 2 & =\sqrt{\left(1-R^{2}\right)} \\
& =\sqrt{\left(1-0,571^{2}\right)} \\
& =\sqrt{0,673} \\
= & 0.820
\end{aligned}
$$

2) Based on the results above, the path coefficient and residual path coefficient of Sub structure 2 can be described as follows:

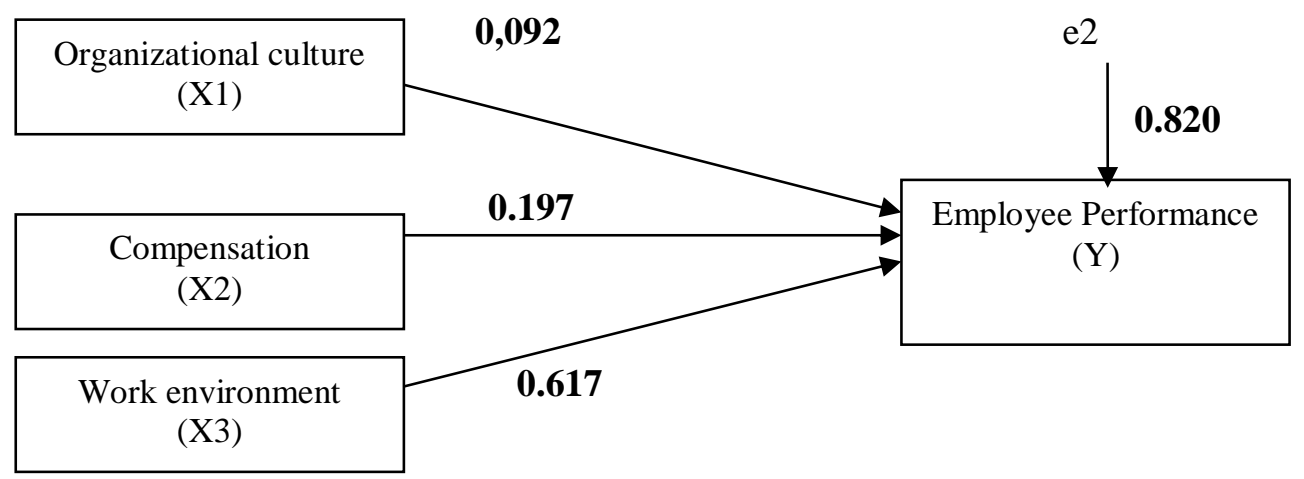

\section{Information}

Figure 8. Sub-line structure 2

e1 : Path coefficient for residual organizational culture (X1), compensation (X2) and work environment (X3) on employee performance (Y) at Bangko Class II Correctional Institution (Lapas).

e2 : Path coefficient for residual organizational culture (X1), compensation (X2), and work environment (X3) on employee performance (Y) at Bangko Class II Correctional Institution (Lapas)

R2 : Coefficient of determination for each path

1 : Constant number

\section{Summarizes Direct and Indirect Influences}

Shows the model presented above where there is a path coefficient so that the price is $\mathrm{p} 31=0.543, \mathrm{p} 32=0.114$, py $1=0.029$, py $2=0.197$, and py $3=0.617$. Thus, a recapitulation of both the direct and indirect effects of exogenous variables on endogenous variables can be prepared with the results as described below.

1) The direct influence between organizational culture (X1) on the work environment (X3).

$$
\begin{aligned}
& (\mathrm{X} 1) \text { with respect to }(\mathrm{X} 3)=\mathrm{p} 31 \times \mathrm{p} 31 \\
& =0.543 \times 0.543 \\
& =0.294849
\end{aligned}
$$

Based on the above calculations, it can be concluded that there is a direct influence of the organizational culture variable (X1) on the work environment (X3), which is 0.294849 or $29.48 \%$. 
426 Jurnal Ilmiah Ilmu Administrasi Publik: Jurnal Pemikiran dan Penelitian Administrasi

Publik

Volume 10 Number 2, July-December 2020. Page 416-438

2) The direct effect of compensation (X2) on the work environment (X3).

$(\mathrm{X} 2)$ with respect to $(\mathrm{X} 3)=\mathrm{p} 32 \mathrm{xp} 32$

$$
=0.012996
$$

$$
=0.114 \times 0.114
$$

Based on the above calculations, it can be concluded that there is a contribution of the direct influence of the compensation variable (X2) on the work environment (X3), which is 0.012996 or $1.29 \%$.

3) Direct influence between organizational culture (X1) on employee performance (Y) at Bangko Class II Correctional Institution (Lapas).

(X1) with respect to $(\mathrm{Y})=$ py1 $\mathrm{x}$ py1

$$
\begin{aligned}
& =0.092 \times 0.092 \\
& =0.008464
\end{aligned}
$$

Based on the above calculations, it can be concluded that there is a direct influence of the organizational culture variable (X1) on employee performance (Y) at Bangko Class II Correctional Institution (Lapas), namely 0.008464 or $0.84 \%$.

4) The direct effect of compensation (X2) on employee performance (Y) at Bangko Class II Correctional Institution (Lapas).

(X2) with respect to $(\mathrm{Y})=$ py2 $\mathrm{x}$ py2

$$
\begin{aligned}
& =0.197 \times 0.197 \\
& =0.038809
\end{aligned}
$$

Based on the above calculations, it can be concluded that there is a contribution to the direct influence of the compensation variable (X2) on employee performance (Y) at Bangko Class II Correctional Institution (Lapas), which is 0.038809 or $3.88 \%$.

5) The direct effect of work environment (X3) on employee performance (Y) at Bangko Class II Correctional Institution (Lapas).

(X3) with respect to $(\mathrm{Y})=$ py3 $\mathrm{x}$ py3

$$
=0.617 \times 0.617
$$$$
=0.380689
$$

Based on the above calculations, it can be concluded that there is a direct influence of the work environment variable (X3) on employee performance (Y) at Bangko Class II Correctional Institution (Lapas), which is 0.380689 or $38.06 \%$.

6) Indirect influence between organizational culture (X1) on employee performance (Y) through the work environment (X3) at Bangko Class II Correctional Institution (Lapas). (X1) with respect to $\mathrm{Y} \Omega \mathrm{X} 3=$ py $1 \times \mathrm{X} 1 \mathrm{X} 3 \mathrm{x}$ py3

$$
\begin{aligned}
& =0.029 \times 0.543 \times 0.617 \\
& =0.030822852
\end{aligned}
$$

Based on the above calculations, it is known that the contribution of the indirect influence of organizational culture variables (X1) on employee performance (Y) at Bangko Class II Correctional Institutions (Lapas) through the work environment (X3) is 0.030822852 or $3.08 \%$. 
7) The indirect effect of compensation (X2) on employee performance (Y) through the work environment (X3) at Bangko Class II Correctional Institution (Lapas).

(X1) with respect to $\mathrm{Y} \Omega \mathrm{X} 3=$ py $2 \times \mathrm{X} 2 \mathrm{X} 3 \times \mathrm{py} 3$

$$
\begin{aligned}
& =0.197 \times 0.114 \times 0.617 \\
& =0.013856586
\end{aligned}
$$

Based on the above calculations, it is known that the contribution of the indirect effect of the compensation variable (X2) on employee performance (Y) at the Bangko Class II Correctional Institution through the work environment (X3) is 0.013856586 or $1.38 \%$.

Based on the results of the calculation of the analysis above, where there is a direct influence of organizational culture variables (X1) on the work environment (X3) of 29.48\%, compensation (X2) to the work environment (X3) by $1.29 \%$, organizational culture (X1) on employee performance (Y) of $0.84 \%$. Variable compensation (X2) on employee performance $(\mathrm{Y})$ is $3.88 \%$, work environment (X3) on employee performance ( $\mathrm{Y}$ ) is $38.06 \% . \%$. Organizational culture variable (X1) on employee performance (Y) at Bangko Class II Correctional Institution (Lapas) through the work environment (X3) is 3.08\%, compensation (X2) for employee performance (Y) at Correctional Institutions (Lapas) Class II Bangko through the work environment (X3) is $1.38 \%$, so it can be arranged in a table summary which can be seen in table 32 below.

Table 25 Summary of Analysis of Direct and Indirect Effects of Exogenous Variables on

\begin{tabular}{|c|c|c|c|c|}
\hline No. & Information & Live (\%) & Indirect $(\%)$ & Total Effect \\
\hline 1. & $\begin{array}{l}\text { Direct effect (X1) on } \\
(\mathrm{X} 3)\end{array}$ & $29.48 \%$ & - & \\
\hline 2. & $\begin{array}{l}\text { Direct effect (X2) on } \\
(\mathrm{X} 3)\end{array}$ & $1.29 \%$ & - & \\
\hline 3. & $\begin{array}{l}\text { Direct effect (X1) on } \\
\text { (Y) }\end{array}$ & $0.84 \%$ & - & \\
\hline 4 & $\begin{array}{l}\text { Direct effect (X2) on } \\
(\mathrm{Y})\end{array}$ & $3.88 \%$ & - & \\
\hline 5. & $\begin{array}{l}\text { Direct effect (X3) on } \\
(Y)\end{array}$ & $38.06 \%$ & - & $38.06 \%$ \\
\hline 6. & $\begin{array}{l}\text { Indirect effect (X1) on } \\
(\mathrm{Y}) \text { through }(\mathrm{X} 3)\end{array}$ & & $3.08 \%$ & \\
\hline 7. & $\begin{array}{l}\text { Indirect effect }(\mathrm{X} 2) \text { on } \\
(\mathrm{Y}) \text { through }(\mathrm{Y})\end{array}$ & & $1.38 \%$ & \\
\hline
\end{tabular}
Endogenous Variables 
428 Jurnal Ilmiah Ilmu Administrasi Publik: Jurnal Pemikiran dan Penelitian Administrasi Publik

Volume 10 Number 2, July-December 2020. Page 416-438

Figure 9. Path Analysis Results

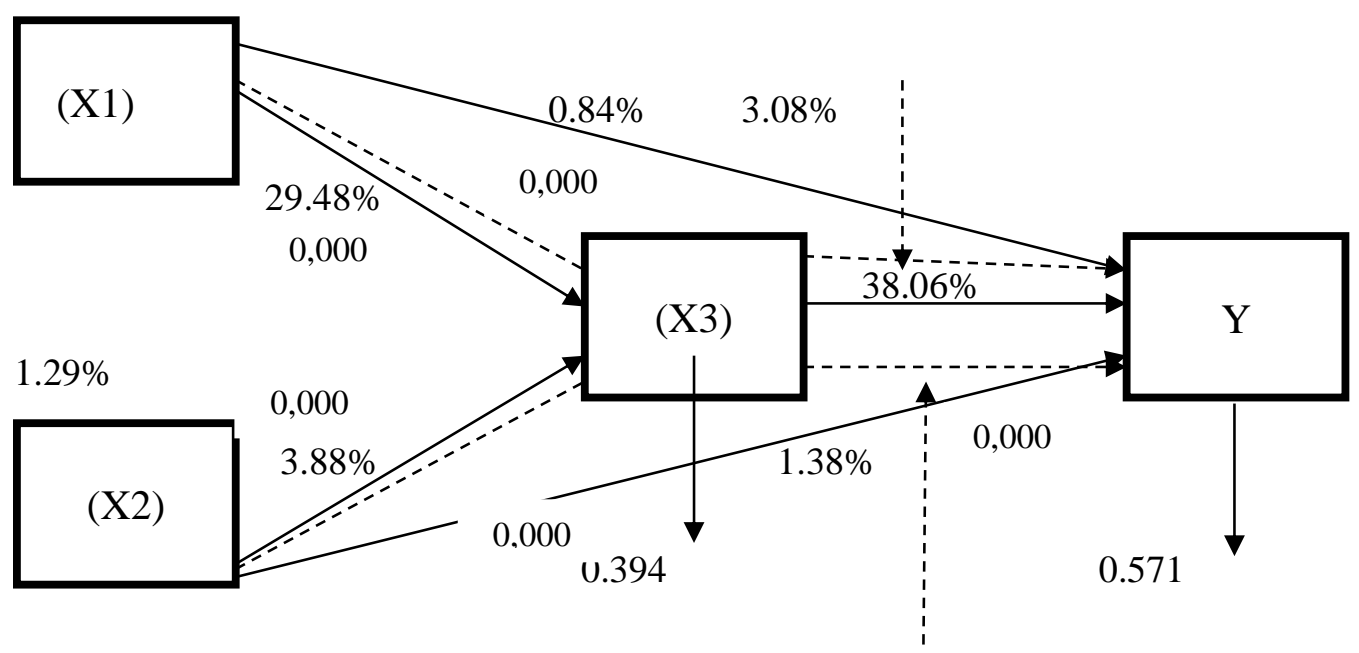

Source: 2020 Research Data Processing Results

\section{B. Discussion}

\section{The Effect of Organizational Culture on the Work Environment}

Based on the results of research conducted by researchers, organizational culture has a direct effect on the work environment at Bangko Class II Correctional Institutions (Lapas). Thus it can be explained that organizational culture can influence the work environment of the Bangko Class II Correctional Institution (Lapas) and is able to significantly influence the work environment of the Bangko Class II Correctional Institution (Lapas). In other words, the better the organizational culture possessed by the Bangko Class II Correctional Institution (Lapas) employees, the better the working environment in the prison and vice versa if the organizational culture of prison employees is lacking, the work environment in the Bangko Class II Correctional Institution will also be better. decreased. Nevertheless, it is still hoped that the head / leadership must pay attention to and improve the organizational culture of every prison employee, and of course there is still a need for direction regarding good organizational culture from the leader or the head of the prison. Because the existence of a good employee organizational culture at the Correctional Institution (Lapas) will certainly have an impact or influence on the job satisfaction of prison employees themselves.

This is reinforced by the opinion of Wirawan (2008) that organizational culture is the norms, values, assumptions, beliefs, philosophy, organizational habits, etc. (the content of organizational culture) developed for a long time by the founders, leaders, and members of the socialized organization. and taught to new members and applied in organizational organizational activities so as to influence the mindset, attitudes, and organizational behavior in producing products, serving consumers and achieving organizational goals. Furthermore, 
according to Darmawan (2013) organizational culture is a set of main belief values and attitudes that are enforced among organizational members. According to Mas'ud (2004) defines organizational culture as a system of meaning, shared values and beliefs in an organization that become a reference for action and differentiate one organization from another. The organizational culture then becomes the identity or the main character of the organization that is maintained and maintained.

The results of this study are also supported by the opinion of Robbins (2006) which states that organizational culture is a shared meaning system shared by organizational members that distinguishes the organization from other organizations. Furthermore, David (2004) states that organizational culture is a pattern of behavior developed by an organization that it learns when it experiences problems of external adaptation and internal integration, which have proven good enough to be validated and taught to new members as a way to realize, think and feel.

So based on the results of research and theoretical studies as well as descriptions of variables that researchers get, the researchers can conclude that organizational culture can affect the work environment of Bangko Class II Correctional Institutions (Lapas) employees, this can be described from organizational culture such as having high innovation and having courage in taking risks, not having a careful attitude in doing work (detail), result oriented, oriented to fellow employees in the office, team oriented, organizational culture that I have to apply in my office is aggressiveness, an employee must have stability in doing work. From the results of the direct influence, it can be seen that organizational culture has an influence value of $29.48 \%$.

\section{Effect of Compensation on the Work Environment}

Based on the results of research conducted by researchers, compensation has a direct effect on the work environment at Bangko Class II Correctional Institutions (Lapas). Thus it can be explained that compensation can affect the work environment of the Bangko Class II Correctional Institution (Lapas) and is able to significantly influence the work environment of the Bangko Class II Correctional Institution (Lapas). In other words, the better the compensation provided by the head or leadership to prison employees in the Class II Bangko Prison, the better the work environment produced by prison employees and vice versa if the compensation received by prison employees is less then the working environment of the Correctional Institution ( Prison) Class II Bangko will decline. It can be said that all compensation indicators are already in the high category. But even so the compensation for Bangko Class II Correctional Institutions (Lapas) employees still needs to be paid close attention to by government agencies and leaders or Heads of Bangko Class II Correctional Institutions (Lapas), because the fulfillment of good compensation and as expected will certainly have an impact or influence on good working environment for the employees of the Class II Bangko Prison itself.

This is also reinforced by the opinion of Rachmawati (2008) that compensation is the entire remuneration received by employees as remuneration from the implementation of work in the organization in the form of money or other, which can be in the form of salaries, wages, bonuses, incentives, and allowances, such as health benefits., holiday allowance, meal allowance, leave and others. In addition, according to Rivai and Sagala (2011), 
430 Jurnal Ilmiah Ilmu Administrasi Publik: Jurnal Pemikiran dan Penelitian Administrasi

Volume 10 Number 2, July-December 2020. Page 416-438

compensation is something that employees receive as a substitute for their service contribution to the organization. The provision of compensation is one of the implementation of the HRM function which deals with all types of giving individual awards as an exchange in carrying out organizational tasks. Furthermore, according to Cardoso in Danang (2012), compensation is anything that is received by workers in return for their work.

Another thing, according to Djati and Khusaini (2003), states that compensation is important because the amount of compensation reflects the size of the value of their work. The compensation program is very important for the company / organization to pay attention to, because it reflects the organization's efforts to maintain human resources and so that employees have high performance at the company. In connection with that matter

Notoamodjo (2009) states that compensation is anything that employees receive as remuneration for their work or service. The objectives of compensation include: respect for work performance, ensuring fairness, retaining employees, obtaining quality employees and controlling costs. Meanwhile, according to Hasibuan (2007) defines compensation as all income in the form of money, direct or indirect goods received by employees as compensation for services provided to the company. Kadarisman (2014) compensation is what an employee receives in return for the job he is given.

So based on the results of research and theoretical studies as well as descriptions of variables that researchers get, the researchers conclude that compensation can affect the work environment of Bangko Class II Correctional Institutions (Lapas) employees, this can be described if compensation such as satisfaction with salaries is not in accordance with the work being done, incentives can make performance at work better, unexpected bonuses from the leadership can improve work, employees in the office must get the same wages, never feel satisfied with the premiums received from the office (leadership, employees must get treatment who deserves a disaster,Employees must have and receive insurance since they start working from the office according to expectations, then theoretically and the results of research will have an impact on a good work environment for Bangko Class II Correctional Institution (Lapas) employees.

\section{The Influence of Organizational Culture on Employee Performance in Bangko Class II Correctional Institutions (Lapas)}

Based on the results of research conducted by researchers, organizational culture has a direct effect on the performance of employees at the Bangko Class II Correctional Institution (Lapas). Thus it can be explained that organizational culture can significantly affect the performance of Bangko Class II Correctional Institution (Lapas) employees and is able to significantly influence the performance of Bangko Class II Correctional Institution (Lapas) employees. In other words, the better the organizational culture possessed by the Bangko Class II Correctional Institution (Lapas) employees, the higher the performance of the Bangko Class II Correctional Institution (Lapas) employees and vice versa if the Bangko Class II Correctional Institution (Lapas) organizational culture is less, the employee performance Bangko Class II Correctional Institution (Lapas) will decline. 
This can be interpreted that the organizational culture possessed by Bangko Class II Correctional Institutions (Lapas) employees even though it is already in the high category, is still expected to government agencies or the Head / leadership of Class II Bangko Correctional Institutions (Lapas) must pay attention to and improve the organizational culture of each. Bangko Class II Correctional Institution (Lapas) employees, and of course there is still a great need for direction regarding a good organizational culture from the leadership or Head of Bangko Class II Correctional Institution (Lapas). Because the existence of a good organizational culture in Bangko Class II Correctional Institutions (Lapas) will certainly have an impact or influence on the performance of Bangko Class II Correctional Institution (Lapas) employees in achieving high work results. still expected to government agencies or the Head / leadership of Bangko Class II Correctional Institutions (Lapas) must pay attention to and improve the organizational culture of each Bangko Class II Correctional Institution (Lapas) employee, and of course there is still a great need for direction regarding good organizational culture from the leadership or Head of the Institution Bangko Class II Correctional Institution. Because the existence of a good organizational culture in Bangko Class II Correctional Institutions (Lapas) will certainly have an impact or influence on the performance of Bangko Class II Correctional Institution (Lapas) employees in achieving high work results. still expected to government agencies or the Head / leadership of Bangko Class II Correctional Institutions (Lapas) must pay attention to and improve the organizational culture of each Bangko Class II Correctional Institution (Lapas) employee, and of course there is still a great need for direction regarding good organizational culture from the leadership or the Head of the Institution. Bangko Class II Correctional Institution. Because the existence of a good organizational culture in Bangko Class II Correctional Institutions (Lapas) will certainly have an impact or influence on the performance of Bangko Class II Correctional Institution (Lapas) employees in achieving high work results. and of course there is still a need for direction regarding a good organizational culture from the leadership or the Head of Class II Bangko Correctional Institution (Lapas). Because the existence of a good organizational culture in Bangko Class II Correctional Institutions (Lapas) will certainly have an impact or influence on the performance of Bangko Class II Correctional Institution (Lapas) employees in achieving high work results. and of course there is still a need for direction regarding a good organizational culture from the leadership or the Head of Class II Bangko Correctional Institution (Lapas). Because the existence of a good organizational culture in Bangko Class II Correctional Institutions (Lapas) will certainly have an impact or influence on the performance of Bangko Class II Correctional Institution (Lapas) employees in achieving high work results.

This is reinforced by Davis's opinion in Mangkunegara (2000) that the factors that affect performance achievement, these factors come from the ability and motivation factors of the apparatus. Timpe (1993) suggests factors that influence performance, namely environment, work motivation, leadership style, behavior, attitudes and actions of colleagues. According to Sinambela (2012), employee performance is defined as the employee's ability to perform certain skills. Employee performance is very necessary, because with this performance it is known to what extent the employee's ability to carry out the tasks assigned to him. 
432 Jurnal Ilmiah Ilmu Administrasi Publik: Jurnal Pemikiran dan Penelitian Administrasi Publik

Volume 10 Number 2, July-December 2020. Page 416-438

According to Rahmatullah (2003) in setiawan and Waridin (2006) performance is basically influenced by three factors, namely: 1) individual factors, including abilities and expertise, background, demographics and work motivation and work discipline, 2) psychological factors, including perceptions, attitude, personality, and learning. 3) organizational factors, including systems or organizational forms of resources, leadership, communication, work environment, organizational culture, awards, structure, training and job design.

According to Luthans (2006) factors that influence employee performance are compensation, salary, leadership, work commitment, work environment or atmosphere, organizational culture, involvement in the organization and work discipline. Furthermore, Mangkunegara (2004) argues that the ability factor and motivation factor. Malthis (2007) there are three factors that can affect how an individual / an employee works, namely 1) individual ability to do the job, 2) level of effort, and 3) organizational support. Individual performance is increased to the extent that these three components are present in the employee, but performance is reduced if one of these factors is reduced or absent.

So based on the results of research and theoretical studies as well as descriptions of variables that the researchers got, it can be concluded that organizational culture can affect the performance of Bangko Class II Correctional Institutions (Lapas) employees, this can be described if organizational culture such as having high innovation and having the courage to take risk, do not have a meticulous attitude in doing work (detail), result oriented, oriented to fellow employees in the office, team oriented, organizational culture that I have to apply in my office is aggressiveness, an employee must have stability in doing work in accordance with expectations then theoretically and the results of the research will improve the performance of the Bangko Class II Correctional Institution (Lapas) employees.

\section{The Effect of Compensation on Employee Performance in Bangko Class II Correctional Institutions (Lapas)}

Based on the results of research conducted by researchers, compensation has a direct effect on employee performance at the Bangko Class II Correctional Institution (Lapas). Thus it can be explained that compensation can significantly affect the performance of Bangko Class II Correctional Institution (Lapas) employees and can significantly influence the performance of Bangko Class II Correctional Institution (Lapas) employees. In other words, the better the compensation provided by the Head or Head of Bangko Class II Correctional Institution (Lapas) to prison employees, the higher the performance of Bangko Class II Correctional Institution (Lapas) employees and vice versa if the compensation provided is less then the performance of the Correctional Institution (Lapas) employees. ) Class II Bangko will decline.

Furthermore, based on the results of the description of the Bangko Class II Correctional Institution (Lapas) compensation variable, it can be seen that compensation is generally in the high category, this can be seen from the indicators of each compensation such as satisfaction with salaries not yet in accordance with the work being done, incentives can make performance at work is better, unexpected bonuses from the leadership can 
improve at work, employees in the office must get the same wage, never feel satisfied with the premiums received from the office (leadership, employees must get proper treatment if they get accident, employees must have and get insurance since they start working from the office in the "High" category. Even though compensation is already in the high category,the head or head of the Bangko Class II Correctional Institution (Lapas) must still pay attention to and improve the compensation that will be given to Bangko Class II Correctional Institution (Lapas) employees, because the fulfillment of good compensation and in accordance with expectations will certainly have an impact or influence employee performance itself.

This is also reinforced by the opinion of Hasibuan (2007) that performance is a result of work achieved by a person in carrying out the tasks assigned to him based on skills, experience, and seriousness and time. Thus performance can be interpreted as a result of work in quality and quantity achieved by an employee in carrying out his duties in accordance with the responsibilities assigned to him.

According to AA Anwar Prabu Mangku (2000) states that basically performance is the result of work in quality and quantity achieved by an employee in carrying out his duties in accordance with the responsibilities assigned to him. Another opinion is reinforced by Mangkunegara (2004) which defines performance as the quality and quantity of work achieved by an employee in carrying out his duties in accordance with the responsibilities assigned to him. Furthermore, the results of this study are reinforced by Wibowo (2012) which states that performance can be viewed as a process and result of work. In other words, performance is not only about how the work process takes place, but also how the results are achieved from the work.

So based on the results of research and theoretical studies as well as descriptions of variables that researchers get, the researchers conclude that compensation can affect the performance of Bangko Class II Correctional Institutions (Lapas) employees, this can be described if compensation such as satisfaction with salary is not in accordance with the work being done Incentives can make performance at work better, unexpected bonuses from the leadership can increase work, employees in the office must get the same wages, never feel satisfied with the premiums received from the office (leadership, employees must get treatment feasible if you get a disaster, the employee must have and get insurance since starting to work from the office, according to expectations, theoretically and the results of the research will improve the performance of the Bangko Class II Correctional Institution (Lapas) employees.

\section{Effect of Work Environment on Employee Performance in Class II Bangko Penitentiary (Lapasa)}

Based on the results of research conducted by researchers, the work environment has a direct effect on employee performance at Bangko Class II Correctional Institutions (Lapas). Thus it can be explained that the work environment can significantly affect the performance of the Bangko Class II Correctional Institution (Lapas) employees and is able to significantly influence the performance of the Bangko Class II Correctional Institution (Lapas) employees. In other words, the better the working environment in Bangko Class II Correctional Institution (Lapas), the higher the performance produced by Bangko Class II 


\section{4 || Jurnal Ilmiah Ilmu Administrasi Publik: Jurnal Pemikiran dan Penelitian Administrasi Publik \\ Volume 1o Number 2, July-December 2020. Page 416-438}

Correctional Institution (Lapas) employees and vice versa if the Bangko Class II Correctional Institution (Lapas) work environment is not good then The performance of Bangko Class II Correctional Institution employees will decline.

Furthermore, based on the results of the description of the work environment variables for the Class II Bangko Prison, it can be seen that the work environment is generally in the high category, this can be seen from the indicators of each work environment such as work equipment in the office is adequate (adequate), the leadership do not have good service at work, good working conditions are not necessarily a reference in getting maximum work results, the attitude of building cooperation and trust with leaders and colleagues can be a point in the success of working in the "High" category.

Even though the work environment is already in the high category, every indicator that becomes the basis for the work environment variables in Bangko Class II Correctional Institutions (Lapas) requires a role, leadership or Head of Bangko Class II Correctional Institution (Lapas) to always pay attention to and improve the work environment that is even better. Because we know that a good work environment will definitely increase the performance of good employees at work. Therefore this is an important thing that must be considered, because it will affect the performance of the employees themselves.

This is also reinforced by the opinion of Rahmatullah (2003) in setiawan and Waridin (2006) that performance is basically influenced by three factors, namely: 1) individual factors, including abilities and expertise, background, demographics and work motivation and work discipline, 2) factors psychological, including perception, attitude, personality, and learning. 3) organizational factors, including systems or organizational forms of resources, leadership, communication, work environment, organizational culture, awards, structure, training and job design.

According to Luthans (2006) factors that influence employee performance are compensation, salary, leadership, work commitment, work environment or atmosphere, organizational culture, involvement in the organization and work discipline. According to Netisemito (2000) the work environment can be interpreted as various kinds of things or something that is around the worker and can affect him in carrying out the assigned tasks.

According to Sedaryanti (2009) in general, the work environment itself is divided into two parts, namely:

1) the physical work environment, namely all things that are around the place where people work, which can directly or indirectly affect work,

2) non-physical work environment, namely everything that happens in institutions related to the work environment, both relationships with superiors and relationships with colleagues, as well as relationships with subordinates.

So based on the results of research and theoretical studies and descriptions of variables that the researcher got, the researchers can conclude that the work environment can affect the performance of Bangko Class II Correctional Institutions (Lapas) employees, this can be described if the work environment such as work equipment in the office is adequate (adequate), the leadership does not have good service at work, good working conditions are not necessarily a reference in getting 
maximum work results, the attitude of building cooperation and trust with leaders and co-workers can be a point in the success of working in accordance with expectations. theory and research results will improve the performance of Bangko Class II Correctional Institution (Lapas) employees.

\section{CONCLUSION}

Based on the results of hypothesis testing to determine the effect of organizational culture, compensation, and work environment on employee performance at Bangko Class II Correctional Institutions (Lapas). From the results of data processing and discussion as described, it can be concluded that:

1. There is a direct influence of organizational culture on the work environment where the value of the contribution obtained is 0.294849 or $29.48 \%$ which means that organizational culture affects the work environment of Bangko Class II Correctional Institutions (Lapas) and organizational culture needs to be improved again in order to improve the working environment of the Penitentiary. Lapas) Class II Bangko next.

2. There is a direct effect of compensation on the work environment where the value of the contribution obtained is 0.012996 or $1.29 \%$, which means that compensation has an effect on the work environment at Bangko Class II Correctional Institutions (Lapas) and compensation needs to be considered again for the comfort of the work environment at the Penitentiary. Prison) Class II Bangko.

3. There is a direct influence of organizational culture on the performance of employees at Bangko Class II Correctional Institutions (Lapas), where the value of the contribution obtained is 0.008464 or $0.84 \%$ which means that organizational culture greatly affects the performance of employees of the Cla: 135 gko Correctional Institution and organizational culture. need to be improved again in improve the performance of the Bangko Class II Correctional Institution (Lapas) employees in the future.

4. There is a direct effect of compensation on the performance of employees at Bangko Class II Correctional Institutions (Lapas), where the value of the contribution obtained is 0.038809 or $3.88 \%$, which means that compensation has an effect on the performance of Bangko Class II Correctional Institutions (Lapas) employees and compensation needs to be increased again for the sake of improve the performance of Bangko Class II Correctional Institutions (Lapas) employees in the future.

5. There is a direct influence of the work environment on the performance of employees at Bangko Class II Correctional Institutions (Lapas), where the value of the contribution obtained is 0.380689 or $38.06 \%$, which means that the work environment greatly influences the performance of the Bangko Class II Correctional Institution (Lapas) employees and the work environment. need to be improved again in order to improve the performance of the Bangko Class II Correctional Institution staff in the future. 
436 Jurnal Ilmiah Ilmu Administrasi Publik: Jurnal Pemikiran dan Penelitian Administrasi Publik

Volume 10 Number 2, July-December 2020. Page 416-438

\section{REFERENCES}

\section{1. $\underline{\text { Book }}$}

A Dale, Timpe. 1993. Performance. Jakarta: PT. Gramedia.

AA Anwar Prabu Mangkunegara. 2000. Human Resource Management, Bandung. PT, Remaja Rosdakarya.

Achmad S. Ruky, 2001. Performance Management Systems. PT Gramedia, Jakarta.

Agus Wibowo. 2011. Entrepreneurship Education (Concept and Strategy). Yogyakarta: Student Library.

Ahwari. 2000. Personnel Management. GhaliaIndonesia, Jakarta.

Alex S. Nitisemito 2002. Personnel Management. The 9th edition. 4th edition. Jakarta: Ghalia Indonesia.

Ambar Teguh Sulistiyani and Rosidah, 2003, Human Resource Management, Graha Ilmu, Yogyakarta.

Asri Laksmi Riani, M. 2011. Compensation Perspective. Surakarta: Yuma Pustaka.

Bambang, Riyanto, 2011. Basics of Corporate Spending. Yogyakarta: Gadjah Mada publisher foundation.

Bilson, Simamora. 2001. Winning the Market with Effective and Profitable Marketing, First Edition, Jakarta, PT. Gramedia Pustaka Utama.

Bungin, Burhan. 2013. Social \& Economic Research Methodology: Quantitative and Qualitative Formats for Sociology, Public Policy, Communication, Management, and Marketing Studies. Jakarta: Golden.

Bungin, Burhan. 2013. Social \& Economic Research Methodology: Quantitative and Qualitative Formats for Sociology, Public Policy, Communication, Management, and Marketing Studies. Jakarta: Golden

Burhan Bungin. 2011. Quantitative Research Methodology: Communication, Economics, and Public Policy and Other Social Sciences Second Edition. Jakarta: Kencana Media Prenada Group.

Creswell, JW (2010). Research design: qualitative, quantitative, and mixed approaches. Yogjakarta: PT Pustaka Pelajar.

Danang Sunyoto. 2012. Theory, Questionnaires and Data Analysis, Human Resources. Yogyakarta: Exciting Book.

Darmawan, Didit. 2013. Principles of Organizational Behavior. Surabaya: Universal Pen.

David, Fred R. 2004. Strategic Management, Concepts. Seventh Edition, Linguist Alexander Sindoro, Jakarta: Prehalindo.

Dessler, Garry. 1997. Human Resource Management. (Benyamin Molan Translation). Indonesian Edition. PT Prenhallind. Jakarta.

Dessler, Garry. 2005. Human Resource Management. (Eli Tanya's Translation). Ninth Edition, Volume 2. Jakarta PT Index.

Dessler, gary. 2007. Human Resource Management. Volume 2. Jakarta: PT. Index. 
Dharma Agus. 2003. Supervision Management: A Practical Guide for Supervisors, Raja Grafindo Persada, Jakarta.

Djokosantoso, M. 2003. Corporate Culture and Corporate Excellence, Elex Media Komputindo, Jakarta.

Fred Luthans. 2006. Organizational Behavior. Issue Ten, PT. Andi: Yogyakarta.

Fuad Mas'ud, 2004, "Organizational Diagnosis Survey," Diponegoro University Publishing Agency, Semarang.

Ghozali, Imam. 2013. Application of Multivariate Analysis with the IBM SPSS 21 Update PLS Regression Program. Semarang: Diponegoro University Publishing Agency.

Gie, The Liang. 2000. Modern Office Administration. Yogyakarta. Liberty.

Gomes, Faustino Cardos. 2003. Human Resource Management. Second edition. Publisher Andi Offset, Yogyakarta.

Gorda, I Gusti Ngurah. 2004. Human Resource Management. Singaraja: STIE Satya Dharma.

Greenberg, Jerald and Baron, Robert A. 2000. Organizational Behavior. Jakarta: Prentice Hall.

Griffin, RW, \& Ebbert, RJ 2014. Business. Jakarta: Erlangga.

Hasibuan, Malayu.SP 2005. Human Resource Management. Revised Edition. Jakarta: Earth Literacy.

Heidjrachman Ranupandojo and Suad Husnan. 1990. Personnel Management. Yogyakarta: BPFE.

Kreitner, R. and K. angelo. 2003. Organizational Behavior, Book I, Salemba Empat, Jakarta.

Kreitner, Robert and Kinicki, Angelo. 2003. Organizational Behavior. Translation of Erly Suandy, Jakarta: Four Salemba, First Edition. I

Lewa, S. 2005. Behavior and Organizational Culture. Bandung: PT. Refika Aditama.

Mahsun, Mohamad. 2009. Public Sector Performance Measurement, Yogyakarta: BPFE.

Mangkunegara, AA Anwar Prabu. 2002. Performance Evaluation of HR, Bandung: PT Rafika Aditama, First Edition.

Mangkunegara, Anwar Parbu. 2006. Company Human Resource Management. Youth Rosdakarya, Bandung.

Mangkunegara, Anwar Prabu. 2000. Human Resource Management. Bandung:

Terry, George R. 2006. Principles of Management. Jakarta: Earth Literacy. I

Triguno. 2004. Work Culture: Creating a Conducive Environment to Increase Work Productivity. Jakarta: Golden Trayon Press.

Umar, Husein. 2007. Evaluation of company performance. Jakarta: Gramedia Pustaka Utama.

Utrisno, Edy. 2010. Human Resource Management. Jakarta: Kencana. Teguh Sulistiyani Ambar \& Rosidah. 2003. Human Resource Management. Concept of Theory and Development in the Context of Public Organizations. Graha Science: Yogyakarta.

Wibowo. 2012. Performance Management, Third Edition. Jakarta: PT Raja Grafindo Persada.

Wilson Wake up. 2012. Human Resources Management. Jakarta. Erlangga.

Hero. 2009. Performance Evaluation of Human Resources Application Theory and Research. Jakarta. Publisher: Salemba Empat. 
438 Jurnal Ilmiah Ilmu Administrasi Publik: Jurnal Pemikiran dan Penelitian Administrasi Publik

Volume 10 Number 2, July-December 2020. Page 416-438

\section{Research journal}

A. Aji Tri Budianto. 2015. "The Effect of Work Environment on Employee Performance at PT Perusahaan Gas Negara (Persero) Tbk SBU Jakarta Area Distribution", Management Study Program Scientific Journal, Vol. 3, No.1, October 2015, Pamulang University.

Agustina Setyo Utami. 2017. "The Influence of Organizational Culture, Motivation and Work Discipline on Employee Performance at KSP LOHJINAWE", Journal of Business Administration, Vol. 6, No.3, Diponegoro University.

Ahmed. et al 2014, The Impact of Organizational Culture on Organizational Performance: A Case Study of Telecom Sector, Global Journal of Management and Business Research: A Administration and Management, 14 (3): 21-30.

Ahmudi. 2018. "The Effect of Work Motivation, Competence, and Compensation on Job Satisfaction and Its Impact on Employee Performance (Case Study of PT XYZ)", IENACO National Seminar, ISSN. 2337-4349, Diponegoro University.

Kasenda, Ririvega. 2013. "Compensation and Motivation Affects Employee Performance at PT.Bangun Wenang Beverages Company Manado". ISSN 2303-1174. Emba Journal Volume 1. Number 3. Pg 853859.

Lies Indriyanti. 2009. Analysis of the Effect of Compensation and Work Environment on Work Productivity of Nurses with Job Satisfaction as a Mediation Variable. Journal of Economics-Management-Accounting, N0. 26, Th XVI, pp. 117-127.

Lijian Poltak sinambela. 2014. Quantitative Research Methodology for Administration, Public Policy, Economics, Sociology, Communication and Other Social Sciences. Yogyakarta: Graha Science.

Masrukhin and Waridin. 2006. Effect of Work Motivation, Job Satisfaction, Organizational Culture and Leadership on Employee Performance, Journal of Economics \& Business. Vol. 7, No. 2.

Zackaria Rialmi. 2017. "The Effect of Procedural Justice applied to Employee Leadership and Employee Job Satisfaction on the Performance of BPBD Riau Province Employees", Jurnal Mandiri, Vol. 1, No.2, December 2017, ISSN. 2580-3220, Pamulang University.

Zainul Hidayat. 2012. "The Influence of Work Environment and Work Discipline and Work Motivation on Employee Performance of Regional Drinking Water Companies (PDAM) Lumajang Regency", WIGA Journal, Vol.2, No.1, March 2012, ISSN.2088-0944, STIE Widya Gama Lumajang . 